\title{
A monograph on amylases from Bacillus spp.
}

\author{
Sailas Benjamin", R. B. Smitha, V. N. Jisha, S. Pradeep, S. Sajith, S. Sreedevi, Prakasan Priji, \\ K. N. Unni, M. K. Sarath Josh
}

Enzyme Technology Laboratory, Biotechnology Division, Department of Botany, University of Calicut, Kerala, India Email: ${ }^{*}$ sailasben@yahoo.co.in

Received 1 January 2013; revised 31 January 2013; accepted 7 February 2013

\begin{abstract}
Owing to the production of alpha, beta and gamma amylase subtypes; starch degrading microbes, especially bacteria have an invincible role in the food, fermentation, textile and paper industries. Of them, $\alpha$-amylases from Bacillus spp. have contributed tremendous advancements in bio-industry, especially in starch, detergent and pharmaceutical arena. Though general reviews are seen in literature on amylases, no focused review is available yet solely on $\alpha$-amylases produced by Bacillus spp. Hence, this focused review on $\alpha$-amylases from the genus Bacillus is designed in such a way that it should give a vivid picture on most of the aspects on bacillial $\alpha$-amylases in a handy module with an industrial perspective. With a short introduction on amylases in general, $\alpha$-amylases from various species of Bacillus reviewed herein encompasses production of $\alpha$-amylases by submerged and solid-state fermentations; nutrients and other factors required for maximizing production; immobilization strategies for whole cells or purified enzyme; an overview on the molecular weight of the enzyme; followed by distinct sections for purification, characterization, stability and crystal structure; and concluded with a section on industrial applications of the $\alpha$-amylases from Bacillus spp.
\end{abstract}

Keywords: Bacillus; Amylases; Production; Fermentation; Crystal; Immobilization; Stability; Molecular Weight; Characteristics; Applications

\section{INTRODUCTION}

Enzymes are among the most important products obtained for human needs through microbial sources. A large number of processes in the areas of industrial, environmental and food biotechnology utilize enzymes at some stage or the other. Industrial enzyme market is an oligopoly with few strong players (amylases, proteases and lipases), and amylases are one among them. Amy-

*Corresponding author. lases are glycosidases which catalyse the hydrolysis of glycosidic linkage in starch to generate smaller sugars useful to bioprocess in bioindustry [1]. Although amylase can be derived from several sources - such as plants, animals and microorganisms - those obtained from microbial sources generally meet the industrial demands. The amylase family of enzymes has well been characterized through the study of various microorganisms. Amylases are traditionally produced by submerged or liquid fermentation $(\mathrm{SmF})$ system. Of late, owing to its proven advantages, solid-state fermentation (SSF) advanced a lot to supersede the conventional SmF. SmF has been preferred for the production of industrially important enzymes because of the ease of handling and greater control of environmental factors such as temperature and $\mathrm{pH}$ [2]. Utilization of agro-industrial residues or effluents as medium for the fermentation received growing interests as they are inexpensive energy-rich sources and also eliminates large-scale accumulation of the biomass, and thus most of the commercial processes are based on SmF [3].

\section{Classification of Amylases}

Amylases are extracellular enzymes and classified into three subtypes, viz., $\alpha$-amylase, $\beta$-amylase and $\gamma$-amylase. Unlike $\beta$-amylase, $\alpha$ - and $\gamma$-amylases are produced in animal systems abundantly, and all these three enzymes are produced by plants, yeast, fungi and bacteria. Four groups of starch converting enzymes have been identified viz., endoamylases, exoamylases, debranching enzymes and transferases [4]. Endoamylases cleave $\alpha-1,4$ glycosidic bonds present in the amylose or amylopectin chain - the structural components of starch made of sugars - in a random fashion and $\alpha$-amylase is a well known endoamylase. Exoamylases such as $\beta$-amylase and glucoamylase cleave both $\alpha-1,4$, and/or $\alpha-1,6$ glycosidic bonds $[4,5]$.

Alpha amylase (EC 3.2.1.1): is alternatively known as 1,4- $\alpha$-D-glucan glucanohydrolase or glycogenase [6]. The $\alpha$-amylases are calcium metalloenzymes, i.e., the divalent calcium ion is invincible for its function [7]. By 
acting at random locations along the starch chain, $\alpha$ amylase breaks down long-chain carbohydrates, ultimately yielding maltose and maltotriose from amylose or maltose, glucose and "limit dextrin" from amylopectin [8]. The hydrolytic products have $\alpha$-configuration. As it can act anywhere on the substrate, $\alpha$-amylase tends to be faster-acting than $\beta$-amylase [9].

Beta amylase (EC 3.2.1.2): is synonymous as 1,4$\alpha$-D-glucan maltohydrolase, glycogenase or saccharogen amylase synthesised by bacteria, fungi and plants [10]. Working from the non-reducing end, $\beta$-amylase catalyses the hydrolysis of the second $\alpha-1,4$ glycosidic bond, cleaving off two glucose units (maltose) at a time [11]. During the ripening of fruit, $\beta$-amylase breaks starch into sugar, resulting in the sweet flavour of ripe fruits. $\beta$ amylase appears prior to germination, whereas $\alpha$-amylase and proteases appear once germination has begun. Amylase from the cereal grains is the key source to the production of malt. Many microbes also produce amylase to degrade extracellular starches [12]. Animal tissues do not possess $\beta$-amylase, although it may be present in microorganisms contained within the digestive tract (probiotics).

Gamma amylase (EC 3.2.1.3): is also known as glu- can 1,4- $\alpha$-glucosidase, amyloglucosidase, exo-1,4- $\alpha$-glucosidase, glucoamylase, lysosomal $\alpha$-glucosidase or $1,4-$ $\alpha$-D-glucan glucohydrolase [13]. In addition to cleaving the last $\alpha-(1-4)$-glycosidic linkages at the non-reducing end of amylose and amylopectin yielding glucose, $\gamma$ amylase will also cleave $\alpha-(1-6)$-glycosidic linkages [13]. Unlike the other forms of amylases, $\gamma$-amylase is best active in acidic environments [14].

\section{2. $\alpha$-AMYLASE PRODUCTION BY SUBMERGED FERMENTATION (SmF)}

Conventionally industry prefers $\mathrm{SmF}$ for the large scale production of microbial enzymes due its easiness in controlling the process parameters, for which commercial media formulations are used. Bacillus spp. secrte a variety of enzymes including polysaccharases, proteases and nucleic acid hydolysing enzymes. Amylase from $B$. subtilis was considered as an industrial enzyme as early as 1917, but commercial production of this enzyme began in the late 1940s with the introduction of submerged culture or fermentation $(\mathrm{SmF})$ borrowed from antibiotic industry [15]. Currently, a limited number of strains of selected species are used to prepare major seven enzymes including $\alpha$-amylases on a large scale. Bacillial

Table 1. $\alpha$-Amylase production of bacillial spp. in various media with or without starch supplement by SmF.

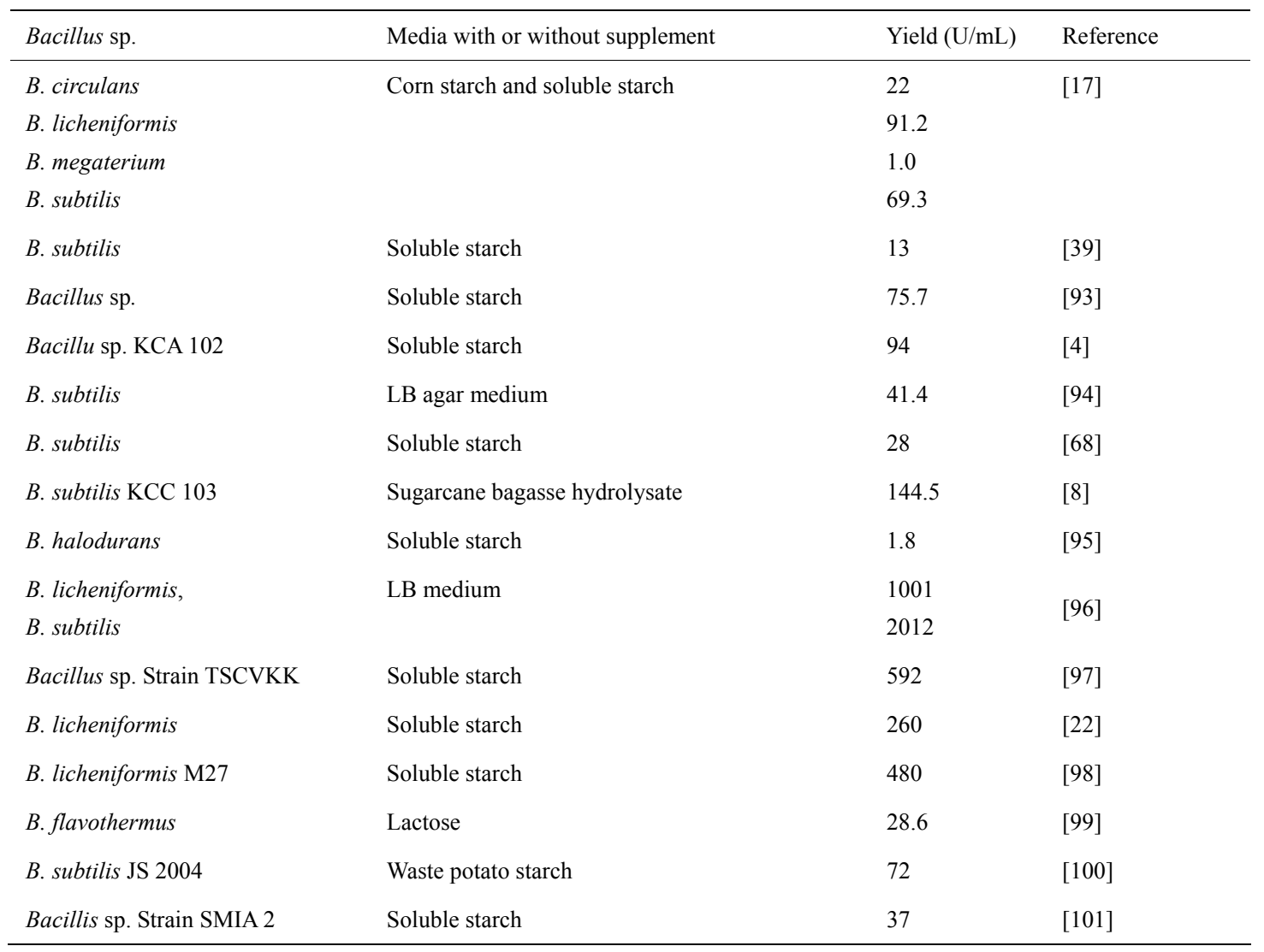


species like B. amyloliquefaciens, B. licheniformis, $B$. stearothermophilus and $B$. subtilis are the major producers of $\alpha$-amylases [16]. Table 1 illustrates media vs. enzyme production by various species or strains of Bacillus.

Bacillus spp. grows at different rate with specificity to different substrates in culture medium [17]. Complex or semisynthetic medium seems to be better for amylase production. Most of the media formulations use soluble starch as the principal carbon source in liquid media, whose percentage normally varies between 1 to 2 [18-20] which may be in combination with peptone [19] or yeast extract $[19,20]$ or beef extract [21] or triptone [18]. Many authors evaluated efficacy of simple sugars such as lactose and glucose in combinations with nitrogen sources for amylase production using Bacillus. sp. As-1w [19] and B. licheniformis [22], and their efficiency was not promising in comparison to soluble starch or extracted starch from agricultural products like white corn [17] . Efficiency of $B$. licheniformis to thrive on starch from hordium, pearl millet, rice, corn, gram and wheat starch has been evaluated for the production of $\alpha$-amylase [23], of which pearl millet starch (1.5\%) significantly enhanced amylase production, which was also reconfirmed independently by another group [24].

Application of response surface methodology (RSM) for the optimization of medium and growth parameters found great advancement in reducing labour and time. RSM was efficiently used to study the cumulative interactive effect of the macronutrients (soybean meal, yeast extract and wheat bran) of the media and to optimize their concentrations to enhance the production (up to $25 \%$ ) of maltooligosaccharide-forming amylase from $B$. circulans GRS 313 [25], or another combination comprising starch, glycerol, yeast extract and peptone from Bacillus sp. [26], wheat bran and groundnut oil cake mixture (1:1 ratio) cultural parameters for the cultivation of B. amyloliquefaciens in liquid state [27].

Like medium, controlled aeration also play a major role in maximizing the yield of $\alpha$-amylase; and in general, lower agitation rate would be better for maximal $\alpha$ amylase synthesis [28]. Mostly, maximum amylase production was noticed at 12 to $20 \mathrm{~h}$ of fermentation $[4,18]$ or $24 \mathrm{~h}$ as in a batch process employing B. licheniformis [29]. Normally, Bacillus spp. prefer neutral or slightly alkaline or a range between 6.8 and $7.2 \mathrm{pH}$ for amylase production at the initial stage of fermentation.

Various authors use different units of amylase activity for the interpretations of results. Predominantly $\mathrm{U} / \mathrm{mL}$ is being used for $\mathrm{SmF}$, but some authors used U/cfu (units per colony forming units) [17]. Established measure is the International Unit (IU) per $\mathrm{mL}$ culture medium in $\mathrm{SmF}$, i.e., micromoles of the product formed per minute [1]. For instance Ajayi and Fagade [17] demonstrated different growth profiles and substrate specificites of five species of Bacillus; and that the amylase production values ranged from $0.22 \times 10^{2} \mathrm{U} / \mathrm{cfu}$ by $B$. circulans to $0.912 \times 10^{2} \mathrm{U} / \mathrm{cfu}$ by $B$. licheniformis from corn starch and $0.01 \times 10^{2} \mathrm{U} / \mathrm{cfu}$ by both $B$. megaterium and $B$. licheniformis to $0.693 \times 10^{2} \mathrm{U} / \mathrm{cfu}$ by $B$. subtilis from soluble starch. It seems very difficult to compare the activities between $\mathrm{U} / \mathrm{cfu}$ and $\mathrm{U} / \mathrm{mL}$, hence it is always preferred to use the units of enzyme activity in $\mathrm{U} / \mathrm{mL}$ when $\mathrm{SmF}$ is the fermentation strategy. When liquid media supplements (like extracts of agricultural residues) are used for $\mathrm{SmF}$, it would be easy to compare if the values are given as liquid equivalents, i.e., the control liquid medium, preferably a standard medium like LB or nutrient broth [1]. From SmF studies, it is evident that $B$. licheniformis and $B$. subtilis are the major producers of bacillial $\alpha$-amylases. In general perspective and considering the thermostability, $\alpha$-amylase from $B$. licheniformis is mostly preferred by the industry.

\section{3. $\alpha$-AMYLASE PRODUCTION BY SOLID-STATE FERMENTATION (SSF)}

Current developments in biotechnology paved avenues for the novel applications of enzymes; accordingly the production strategies have been revolutionized. SmF has traditionally been used for the production of industrially important enzymes. In comparison, SSF with optimized production parameters seems to be better for enhanced amylase production [1]. Solid-state (substrate) fermentation (SSF) holds tremendous potential for the enhanced production of such industrially-significant enzymes. SSF has been defined as the fermentation process occurring in the absence or near-absence of free water [30] and it has become a very attractive alternative to $\mathrm{SmF}$ for specific applications due to the recent improvements in reactor designs [1]. SSF processes generally employ a natural and very cheap raw material as sole source of carbon and energy [30]. It can also be employed on inert material as solid matrix/support, which requires supplementing a nutrient solution containing necessary ingredients including carbon and nitrogen sources.

SSF has emerged as a potential technology for the production of microbial products such as feed, fuel, food, industrial chemicals and pharmaceutical products [31]. Its application in bioprocesses such as bioleaching, biobeneficiation, bioremediation, biopulping, etc. has offered several advantages such as higher fermentation productivity, higher end-concentration of products, higher product stability, lower catabolic repression, coupled with cultivation of microorganisms specialised for waterinsoluble substrates and lower demand on sterility due to the low water activity used in SSF.

Agricultural residues offer a valuable substrate for amylase production by SSF (Table 2). As far as SSF is 
Table 2. $\alpha$-Amylase production of bacillial spp. on various solid media by SSF.

\begin{tabular}{llll}
\hline \multicolumn{1}{c}{ Bacillus sp. } & Solid substrate & Yield (U/gds) & Reference \\
\hline $\begin{array}{l}\text { B. cereus } \\
\text { B. subtilis }\end{array}$ & rice bran, wheat bran, sugarcane bagasse, & 386 & {$[34]$} \\
B. licheniformis M27 & black gram husk and green gram husk banana waste & 7.27 & {$[36]$} \\
B. licheniformis & Wheat bran & 21,000 & {$[102]$} \\
B. subtilis & Potato peel and wheat bran & 270,175 & {$[33]$} \\
B. megaterium 16M & Wheat bran & 600,265 & {$[33]$} \\
B. subtilis & Wheat bran & 30,000 & {$[32]$} \\
B. subtilis & Wheat bran and rice husk & $159,520 \& 21,760$ & {$[37]$} \\
Bacillus sp. & Banana peel & 9 & {$[35]$} \\
Bacillus sp. PS-7 & Wheat bran and lentil husk & $172,800 \& 216,000$ & {$[103]$} \\
B. cereus & Wheat bran & 464,000 & {$[42]$} \\
B. amyloliquefaciens & Wheat bran and rice flake manufacturing waste & 122 & {$[104]$} \\
Bacillus sp. & WB + Ground nut oil cake(1:1) & 62,470 & {$[105]$} \\
B. subtilis SDA3, & Potato peel & 270 & {$[33]$} \\
B. circulans & Dehulled cooked soybean into soy-daddawa (a \\
B. subtilis DSM 347, & Whendiment) & 4.0 & {$[106]$} \\
\hline
\end{tabular}

concerned, wheat bran seems to be the preferred substrate of interest for many investigators for $\alpha$-amylase production [27,32-34]. Other agricultural residues like potato peel [33]; banana peel [35]; banana residue including whole plant after harvest [36]; residues generated during agricultural processing such as lentil husk [37]; rice bran, wheat bran, sugarcane bagasse, black gram husk, green gram husk [34], etc., seem to be efficient substrates. The success of SSF greatly depends on the appropriate incubation period, inoculum size, moisture level, suitable nitrogen source and $\mathrm{pH}$ requirements [1].

Interestingly, in situ fermentation using microbes bearing GRAS (generally regarded as safe) label to enhance the palatability and flavour of vegetables, pulses and other agricultural raw food stuffs is getting more attention in these days [38]. B. subtilis was found efficient to make Okpehe, a traditional fermented condiment in Nigeria; among other enzymes, amylase $(13 \mathrm{U} / \mathrm{mL})$ also contributed to the nutritional enrichment Okpehe [39]. B. subtilis was also used to convert sterile dehulled cooked soybean into soy-daddawa (a condiment) by the $\alpha$-amylase $\left(48 \mathrm{~h}, 35^{\circ} \mathrm{C}\right.$ ). These studies show that in situ fermentation under controlled conditions for improving the organoleptic values of the raw food stuff, thereby increasing the price and shelf-life of the products which would in turn benefit the framers.
The activity of enzymes produced by SSF is normally expressed in U/gds (units per gram dry fermented substrate) [40]. However, when cross comparison of enzyme activities obtained from SmF and SSF is required, the authors may use confusing units of their choice, which may lead to false positive emphasis to the actual results.

\section{OTHER NUTRIENTS FAVOURING $\alpha$-AMYLASE PRODUCTION}

Carbon $(\mathrm{C})$ and nitrogen $(\mathrm{N})$ sources, coupled with their proper blends are important parameters required for offering better growth of the microbes during fermentation. Optionally, multi-protein mineral media containing initial $2.5 \%$ or $3.5 \%$ concentration of starch and subsequent addition of $2 \%$ (at about $24 \mathrm{~h}$ after initiation of fermentation) was found better for the enhanced production of $\alpha$-amylase [41]. Starch and tryptone were found ideal C and $\mathrm{N}$ sources, respectively for the production of amylase from $B$. thermooleovorans, but in a chemically defined medium consisting of glucose, riboflavin, cysteine, $\mathrm{MgSO}_{4}, \mathrm{~K}_{2} \mathrm{HPO}_{4}$ and $\mathrm{NaCl}$, production increased by 2 -fold [18]. Process parameters such as optimum substrate concentration, incubation period $(42 \mathrm{~h})$ and $\mathrm{CaCl}_{2}$ $(0.0275 \mathrm{M})$ requirements in the production medium emerge as crucial rate-limiting factors [27]. By SSF, 
Sodhi et al. [42] found that Bacillus sp. PS-7 could produce a maximum of 464,000 U/gds (gram dry substrate) $\alpha$-amylase on wheat bran supplemented with $1 \%$ glycerol, $1 \%$ soybean meal, $0.1 \%$ proline, $0.01 \%$ vitamin $\mathrm{B}$-complex, $1 \%$ Tween $40,1 \mathrm{mM} \mathrm{MgSO}_{4} \cdot 7 \mathrm{H}_{2} \mathrm{O}$ at $48 \mathrm{~h}$ and $37^{\circ} \mathrm{C}$; in this complex medium, $\mathrm{CaCl}_{2}$ was not specifically added. In fact, presence of $\mathrm{CaCl}_{2}[20,36]$ and $\mathrm{MgSO}_{4}$ [36] would boost the yield of $\alpha$-amylase; also $\mathrm{Ca}$, $\mathrm{Mg}$ and $\mathrm{Na}$ ions are implicated to play a major role in its yield and activity [1].

\section{OTHER FACTORS CONTROLLING $a$-AMYLASE PRODUCTION}

Enrichment of medium for fermentation is very much significant to maximize amylase production. Carbohydrates such as starch, dextrin, glycogen, cellobiose, maltohexaose, maltopentaose, maltotetraose and maltotriose were used for the enrichment culture of B. stearothermophilus in a complex medium containing beef extract or corn steep liquor [21]. Monosaccharides such as inositol and D-sorbitol have repressed amylase production, while organic and inorganic salts such as $\mathrm{KCl}$, sodium malate and potassium succinate increased the yield than $\mathrm{Na}$ and $\mathrm{K}$ ions. Inclusion of aminoacids such as isoleucine, cysteine, phenylalanine and aspartic acid in the medium was also found vital for amylase production [21]. Detergents like Tween 80 and Triton X-100 may repress the enzyme production with increased biomass. B. amyloliquefaciens requires an optimum phosphate level in the medium for maximum $\alpha$-amylase production by $\mathrm{SmF}$ [43].

As far as aerobic bacilli like B. amyloliquefaciens are concerned, aeration has an influential role in amylase production [44]. Production could be enhanced greatly by changing the shape of flask (baffled and non-baffled), working volume of fermentation media and shaking intensity [44]. The baffled flask (10\% working volume) with $200 \mathrm{rpm}$, significantly increased the enzyme production. By increasing the aeration rate of $1 \mathrm{vv} / \mathrm{m}$ in $3 \mathrm{~L}$ stirred tank bioreactor, amylase activity was increased to 2-fold [44]. However, whenever a fermenter is involved for large scale production, near abolition of gas phase in it would be an essential factor, because it would increase the production (by 2.2 fold) with the reduction in optimal production time or gestation period [18]. Like aeration, optimum temperature, $\mathrm{pH}$ and $\mathrm{CaCl}_{2}$ concentration also significantly increase amylase yield from species like Bacillus sp. AS-1 [19], B. sphaericus [45] and B. amyloliquefaciens [46]. Khan and Husaine [46] used $4 \%(\mathrm{w} / \mathrm{v})$ sago pith residue (hampas) in $0.2 \mathrm{M}$ citrate buffer at $\mathrm{pH}$ 6.0 at temperature $40^{\circ} \mathrm{C}$ and incubated for $6 \mathrm{~h}$ at $100 \mathrm{rpm}$ with an additional supply of $1 \%$ soluble starch. It seems that, though raw starchy substrate would support amylase production by various Bacillus spp., addition of soluble starch $(1 \%-2 \%)$ in the medium will significantly boost the yield.

\section{IMMOBILIZATION OF WHOLE CELL/AMYLASE}

During the past few years, immobilized bacteria (cell factory/reactor) have been considered important for the production of industrially-significant enzymes [47]. Immobilized cells have many advantages over conventional fermentation, where freely suspended cells are used. These include: repeated or prolonged use of cells, easier downstream processing, reduced risk of contamination, continuous fermentation with less sophisticated reactors, etc. The immobilized cell reactor was observed to achieve larger volumetric productivities than either mode of stirred tank fermentations, but achieved an enzyme activity concentration lower than that of the batch stirred tank fermenter.

Immobilization was successfully accomplished for strains of B. subtilis in channeled porous alumina [48]; carrageenan gel [49] or in calcium alginate $(2 \%$ sodium alginate and $\left.3.5 \% \mathrm{CaCl}_{2}, \mathrm{w} / \mathrm{v}\right)[50]$; B. licheniformis in alginate or agar [51]; and B. amyloliquefaciens in macroreticular anionic exchange resin [52]. Amritkar et al. [53] incorporated polymeric substrates or substrate analogue during cross-linking of cellulose to prepare rigid, porous, cross-linked composite affinity matrices for the purification of $\alpha$-amylase from immobilized $\mathrm{Ba}$ cillus sp. B3. All these studies showed significantly higher amylase yields. For instance, strain of $B$. licheniformis showed more than 2 fold increase in enzyme yield upon immobilization in $4 \%$ alginate or agar; with optimal initial cell quantity as $0.6 \%-3 \%$ in agar beads of 3 $\mathrm{mm}$ or $0.4 \%$ in Ca-alginate gel with $5 \mathrm{~mm}$ bead sizes [51].

In order to increase better stability and durability of the biocatalyst, immobilization and chemical modification strategies for the enzymes are being employed. $\alpha$ amylase from $B$. licheniformis was immobilized on various carriers such as cross-linked cellulose matrix [54]; $B$. circulans in calcium alginate beads [25], amylases from B. subtilis on to coconut fibre [55] or of Bacillus sp. in to the magnetic poly glycidyl methacrylate beads [5]. Immobilization of enzymes generally stabilizes their structure and better adaptability to $\mathrm{pH}$ and temperature, coupled with increased half-life [56]. Immobilized amylases offer several advantages: they can be reused; the process can be operated continuously with better controls, easy separation of the products, simpler handling of the materials, alteration of activity and thermostability, effective reduction in process cost and long half-life of the enzyme. Covalent binding has been extensively used as a tool to 
immobilize the enzymes. Immobilization will prolong the activity for several batches as in the casae of $\alpha$-amylase from $B$. licheniformis [54]. Alternatively, addition of polyvinyl alcohol $(0.25 \mathrm{wt} \%)$ [25] or $\mathrm{CaCl}_{2}$ [56] on the reaction system significantly enhanced $\alpha$-amylase activity.

\section{PURIFICATION AND CHARACTERIZATION OF $\alpha$-AMYLASE}

Table 3 gives the summary of purification of amylase from various strains of Bacillus spp. Primary focus of all purification protocols is on ammonium sulphate fractionation and dialysis. Column chromatography employing sephadex [57] or sepharose [57,58] has been the major polymer matrices being used to purify the protein from partially purified ammonium sulphate fraction. Few others have used various affinity matrices for the purification $[59,60]$.

Many authors showed that $\mathrm{Ca}^{2+}$ was essential for the stability and enhanced activity of $\alpha$-amylases from $\mathrm{Ba}$ cillus spp. $[42,60,61]$. Cations like $\mathrm{Ca}^{2+}, \mathrm{Na}^{+}, \mathrm{Mg}^{2+}$ showed stimulatory effect for amylase from $B$. licheniformis; while $\mathrm{Ag}^{+}, \mathrm{Hg}^{2+}, \mathrm{Cu}^{2+}, \mathrm{Ni}^{2+}, \mathrm{Zn}^{2+}, \mathrm{Fe}^{2+}, \mathrm{Co}^{2+}, \mathrm{Cd}^{2+}$, $\mathrm{Mn}^{2+}$ and $\mathrm{Al}^{3+}$ showed inhibitory effect $[60,61]$ and anions like azide, $\mathrm{SO}_{3}^{2-}, \mathrm{SO}_{4}^{3-}, \mathrm{S}_{2} \mathrm{O}_{3}^{2-}, \mathrm{MoSO}_{4}^{2-}$ showed excitant effect [60]. In fact, $\mathrm{Cu}^{2+}$ and $\mathrm{Fe}^{2+}$ (but not $\mathrm{Ca}^{2+}$ ) were shown to have protective effects for amylase from B. licheniformis against EDTA-induced activity loss [60]. Contrary to the above reports, an alakaliphilic amylase from Bacillus sp. was strongly inhibited by $\mathrm{Ca}^{2+}, \mathrm{Zn}^{2+}$, $\mathrm{Mg}^{2+}, \mathrm{Mn}^{2+}, \mathrm{Ba}^{2+}$ and $\mathrm{Cu}^{2+}$, whereas presence of $\mathrm{Na}^{+}$, $\mathrm{Co}^{2+}$ and EDTA significantly enhanced the enzyme activity; and this feature is interesting to investigate at the molecular level [62]. Arikan [63] demonstrated that an amylase from Bacillus sp. A3-15 was inhibited by $\mathrm{ZnCl}_{2}$, $\mathrm{NaCl}, \mathrm{CaCl}_{2}, \mathrm{Na}_{2} \mathrm{~S}$, EDTA, urea and SDS and of $B$. subtilis was inhibited by the metal ions $\mathrm{Cu}^{2+}, \mathrm{Zn}^{2+}, \mathrm{Ba}^{2+}$, $\mathrm{Mg}^{2+}, \mathrm{Mn}^{2+}, \mathrm{Ca}^{2+}, \mathrm{Co}^{2+}, \mathrm{Cs}^{2+}, \mathrm{Cd}^{2+}, \mathrm{Fe}^{2+}, \mathrm{Hg}^{2+}$ and $\mathrm{Ni}^{2+}$ [64]. In general, if metal ion requirement is found essential for amylase activity, $\mathrm{Ca}^{2+}$ is the preferred ion for the stability and prolonged half-life of the enzyme [1].

Roles of temperature and $\mathrm{pH}$ on $\alpha$-amylase activity seem to the interrelated. The temperature range for $\alpha$-amylase activity varies from $40^{\circ} \mathrm{C}$ for an alkalophilic Bacillus sp. [62] to $95^{\circ} \mathrm{C}$ for amylases from B. amyloliquefaciens and B. subtilis [41]. However, most of the amylases are optimum active at around $65^{\circ} \mathrm{C}$ in a neutral $\mathrm{pH}$ environment $[42,63,65]$. It further shows that thermolabile amylases are mostly alkalophilic [62], while

Table 3. Activity and yield of bacillial $\alpha$-amylases purified by various strategies.

\begin{tabular}{|c|c|c|c|c|c|}
\hline Bacillus species & Purification strategy & Activity (U/mg) & Yield (\%) & Purification (fold) & Reference \\
\hline B. licheniformis & CMC column & 882.7 & 42 & 211.67 & {$[60]$} \\
\hline Bacillus sp. & QAE column & 18.5 & 2.4 & - & {$[62]$} \\
\hline B. licheniformis & $\begin{array}{l}\text { Sephadex G-100, mono Q Sepharose } \\
\text { anion exchange columns }\end{array}$ & 178.5 & 15.9 & 3.08 & {$[57]$} \\
\hline B. amyloliquefaciens & $\begin{array}{l}\text { Q-Sepharose \& SP-Sepharose } \\
\text { columns }\end{array}$ & 31354 & - & - & {$[6]$} \\
\hline Bacillus sp. B3 & AA-CELBEADS immobilisation & 60.8 & - & 11.9 & {$[53]$} \\
\hline Bacillus sp. YX-1 & $\begin{array}{l}\text { DEAE-Sepharose Fast Flow \& } \\
\text { Sephadex G-75 columns }\end{array}$ & 607 & 6.60 & 34 & {$[108]$} \\
\hline B. subtilis DM-03 & $\begin{array}{l}\text { DEAE Sephadex A-50, Sephadex } \\
\text { G-50 \& RP-HPLC columns, }\end{array}$ & 1421 & 2.9 & 80.5 & {$[109]$} \\
\hline $\begin{array}{l}\text { Geobacillus thermodenitrificans } \\
\text { HRO-10 }\end{array}$ & $\begin{array}{l}\text { DEAE Sephadex A-50 and Superdex } \\
-200 \text { columns. }\end{array}$ & 684.3 & 11.5 & 13.6 & {$[66]$} \\
\hline B. licheniformis & Starch column & 507 & 51 & 230 & {$[59]$} \\
\hline B. subtilis KCC-103 & DEAE Sephadex A 50 & 482.4 & 45.2 & 19.9 & {$[65]$} \\
\hline B. kaustophilus & Metal-chelate column & 39.7 & 49 & 11.4 & {$[110]$} \\
\hline B. subtilis & Sephadex G-75 column & 916.7 & 23.4 & 187.1 & {$[90]$} \\
\hline Lactobacillus amylovorus & Sepharose 6B column & - & 69 & 75 & {$[58]$} \\
\hline B. subtilis $\mathrm{X}-23$ & $\begin{array}{l}\text { Q-Sepharose \& Phenyl Sepharose } \\
\text { columns }\end{array}$ & 362 & 19.5 & - & {$[77]$} \\
\hline
\end{tabular}


thermostable amylases are acidophilic [5,41]; and interestingly, all these amylases would best active at around $\mathrm{pH} 7$ with good half-life.

Vmax and Km are coupled parameters which define the kinetic characteristics of an enzyme as a function of substrate concentration. These kinetic constants are critical to attempts to understand how enzymes work together to control cellular metabolism [30]. Vmax (moles/min) represent the rate of enzyme catalysis. $\mathrm{Km}$ (moles/L) value denotes the affinity of enzyme (here $\alpha$-amylase) to the substrate (starch). Smaller values of $\mathrm{Km}$ indicate that the enzyme and substrate are tightly bound and form the enzyme-substrate complex more quickly, thus more activity. On the other hand, larger values of the $\mathrm{Km}$ constant indicate that the components are loosely bound and form the enzyme-substrate complex more slowly, indicatinbg low activity. Literature shows that $K m$ of $\alpha$ amylase from various species of Bacillus are normally expressed in $\mathrm{mg} / \mathrm{mL}[60,62,65]$ with a value of 2.6 for $B$. subtilis [65], 3.05 for Geobacillus thermodenitrificans [66], $11.7 \mathrm{mg} / \mathrm{mL}$ for B. acidocaldarius strain RP1 [67], etc. However, Vmax has been represented in inconsistent units, which is difficult to correlate for a researcher; e.g., $1.08 \mathrm{mg} / \mathrm{mL} / \mathrm{min}$ for B. licheniformis [60], $909 \mathrm{U} / \mathrm{mg}$ for B. subtilis [65], $0.051 \mu \mathrm{mol} / \mathrm{min}$ for a species of an alkalophilic Bacillus [62], $11.176 \mathrm{mg} / \mathrm{mL} / \mathrm{h}$ for thermophilic B. subtilis strain [68], 600 milliunits $/ \mathrm{mg}$ for $B$. acidocaldarius strain RP1 [67] or $7.35 \mathrm{U} / \mathrm{mL}$ for $\alpha$-amylase secreted by G. thermodenitrificans [66]. From this, it is evident that expression of $K m(\mathrm{mg} / \mathrm{mL}$, though it should have expressed in moles/L) gives seemingly good clarity aand uniqueness of amylase activity, and it normally lies in a range between $1-3 \mathrm{mg} / \mathrm{mL}$, but it may go up to a $\mathrm{Km}$ of $11.7 \mathrm{mg} / \mathrm{mL}$ as in B. acidocaldarius strain RP1 [67]. It is advisable that the authors should stick to the international units of expression, while reporting their findings to the scientific community.

\section{MOLECULAR WEIGHT OF $\alpha$-AMYLASE}

In general, a survey shows that the molecular weight (MW) of $\alpha$-amylase from Bacillus spp. varies between 50 and $60 \mathrm{kDa}$ with some exceptions. Thermostable $\alpha$ amylase from $B$. licheniformis, a monomeric enzyme with molecular mass of $55.2 \mathrm{kDa}$ (483 amino acid residues) showed remarkable heat stability [69]. Liu et al. [70] found that the MW of a thermostable amylase from $B$. licheniformis was $53.13 \mathrm{kDa}$. The extracellular $\alpha$ amylase produced by another strain (44MB82-A) of $B$. licheniformis was $58 \mathrm{kDa}$ as judged by SDS-PAGE [71], but extremely smaller size of amylase $(31 \mathrm{kDa})$ was demonstrated from another strain of B. licheniformis [29]. B. acidocaldarius strain agnano 101 produced an induc- ible thermoacidophilic $\alpha$-amylase, the purified amylase contained a single polypeptide chain of MW $68 \mathrm{kDa}$ [67]. The apparent MW of the purified enzyme from B. amyloliquefaciens was $58 \mathrm{kDa}$ as revealed by SDS-PAGE [27]. Amylase from B. subtilis strain BS5 showed 63 $\mathrm{kDa}$ [72], but another strain of Bacillus sp. produced an amylase whose MW was $126 \mathrm{kDa}$ [73] —which may probably be a dimer.

The nucleotide sequence of the $\alpha$-amylase gene from $B$. stearothermophilus and its flanking regions were determined by [74]. An open reading frame was found, comprising a total of 1647 base pairs (549 amino acids), starting from a GUG codon as methionine. It was shown by $\mathrm{NH}_{2}$-terminal amino acid sequence analysis that the extracellular amylase consisted of 515 amino acid residues, which corresponded to a MW of $58.779 \mathrm{kDa}$. Thus, the $\mathrm{NH}_{2}$-terminal portion of the gene encodes 34 amino acid residues as a signal peptide [74]. N-terminal signal peptides and $\mathrm{C}$-terminal truncation have been characterized in many Bacillus spp. A novel liquefying $\alpha$-amylase was found in cultures of an alkaliphilic Bacillus isolate, KSM-1378 corresponding to 516 amino acids that included a signal peptide of 31 amino acids. The calculated MW of the extracellular mature enzyme was $55.391 \mathrm{kDa}$ [75]. C-terminal truncation has been observed on $\alpha$-amylases of $B$. subtilis [76]. A B. subtilis amylase gene was cloned into a plasmid and expressed in Escherichia coli, the active protein was purified to apparent homogeneity [76]. Its MW (48 $\mathrm{kDa})$ as estimated by SDSPAGE was lower than the molecular mass values calculated from the derived amino acid sequences of the $B$. subtilis complete $\alpha$-amylase ( $57.7 \mathrm{kDa})$. It indicates the removal of the N-terminal signal region from the functional enzymes. Complete $(47 \mathrm{kDa})$ and truncated (67 $\mathrm{kDa}$ ) isoforms of $\alpha$-amylases from $B$. subtilis X-23 were purified, and the amino- and carboxyl-terminal amino acid sequences were determined [77]. The amino acid sequence deduced from the nucleotide sequence of the $\alpha$-amylase gene indicated that truncated form was produced from complete isoform by truncation of the 186 amino acid residues at the carboxyl-terminal region.

\section{STABILITY OF $\alpha$-AMYLASE}

Temperature and $\mathrm{pH}$ optima increase the stability of $\alpha$-amylase. Amylase from B. licheniformis CUMC305 showed many interesting features. The purified enzyme showed maximal activity at $90^{\circ} \mathrm{C}$ and $\mathrm{pH} 9.0$; and $91 \%$ of this activity remained at $100^{\circ} \mathrm{C}$ [60]. The stability of the amylase from $B$. stearothermophilus could be enhanced if liquified thick starch slurries $\left(\right.$ at $80^{\circ} \mathrm{C}$ and $\mathrm{pH}$ 6.9) were provided as feed/substrate in the presence of $\mathrm{Ca}^{2+}$ [21]. Modern molecular insights into the structure of 
amylases and in silico approaches compelled the scientists for schimeric constructs based on the structural gene, the preferred choice for enhacing the stability of amylases. For instance, Suzuki et al. [78] showed that two regions in the amino acid sequence of $B$. licheniformis comprising Gln178 (region I) and the 255 to 270 residues (region II), respectively were shown to determine the thermostability of $B$. licheniformis; region I played the crucial role in determing the thermostability. Tomazic and Klibanov [16] reported that half-lives of Bacillus $\alpha$-amylases at $90^{\circ} \mathrm{C}$ and $\mathrm{pH} 6.5$ greatly increased in the series from $B$. amyloliquefaciens to $B$. stearothermophilus to $B$. licheniformis. This stabilization is achieved by lowering the rate constant of monomolecular conformational scrambling, which was the cause of irreversible thermoinactivation of B. amyloliquefaciens and B. stearothermophilus $\alpha$-amylases, so that deamidation of Asn/ Gln residues for $B$. licheniformis emerged as the cause of inactivation. The extra thermostability of the thermophilic enzyme was found to be mainly due to additional salt bridges involving a few specific lysine residues (Lys-385 and Lys-88 and/or Lys-253).

\section{CRYSTAL STRUCTURE OF $\alpha$-AMYLASE}

The $\alpha$-amylase family is the largest sequence-based family of glycoside hydrolyses (GH13 family) and groups together a number of different enzyme activities and substrate specificities acting on $\alpha$-glycosidic bonds [79]. $\alpha$-amylases are classical calcium-containing enzymes which constitute a family of endo-amylases catalysing the cleavage of $\alpha$-D-( $(1 \rightarrow 4)$ glycosidic bonds in starch and related carbohydrates with retention of the $\alpha$-anomeric configuration in the products [80]. Furthermore, these enzymes are used as targets for drug designing in attempts to treat diabetes, obesity and hyperlipemia [80]. It has long been known that $\alpha$-amylases require calcium for their enzymatic activity.

Crystal structure of many $\alpha$-amylase are known to date as shown in Table 4. It seems that $\alpha$-amylases from $B$. licheniformis and B. subtilis have been the target of many investigators, owing to their predominant role in starch and drug industry. Typically, the $\alpha$-amylases bear a $(\beta / \alpha)$ 8-barrel structure [81]. $\alpha$-amylases with the $(\beta / \alpha)$ 8 -barrel fold are involved in the catalysis of a wide variety of biochemical reactions [82]. The active sites of these enzymes are located on the C-terminal face of the central $\beta$-barrel [69]. Thermostable $\alpha$-amylase from $B$. licheniformis, a monomeric enzyme with molecular mass of $55.2 \mathrm{kDa}$ (483 amino acid residues), shows a remarkable heat stability [69]. Like other $\alpha$-amylases, the polypeptide chain of $B$. licheniformis folds into three distinct domains. The first domain (domain A), consisting of 291 residues (from residue 3 to 103 and 207 to 396), forms a $(\beta / \alpha)$ 8-barrel structure. The second domain (domain B), consisting of residues 104 to 206, is inserted between the third $\beta$-strand and the third $\alpha$-helix of domain A. The third C-terminal domain (domain C), consisting of residues 397 to 482 , folds into an eight-stranded antiparallel $\beta$-barrel [69]. All known structures of holo $\alpha$-amylases show a common calcium-binding site stabilising the interface between the highly homologous central A domain and the more variable B domain. As many crystal structures are known for $\alpha$-amylase, their interrelatedness can easily be deduced by protein modeling [83].

Table 4. Strategies employed for the resolution of crystals from various $\alpha$-amylases of Bacillus spp.

\begin{tabular}{|c|c|c|c|c|}
\hline S1. No & Bacillus sp. & Strategy & Resolution & Ref. \\
\hline 1 & Bacillus sp. Strain KSM-K38 & $\begin{array}{l}\text { Molecular replacement method and refined } \\
\text { to a crystallographic } R \text {-factor of } 19.9 \% \\
(R \text {-free of } 23.2 \%)\end{array}$ & $2.13 \AA$ A resolution & {$[111]$} \\
\hline 2 & B. subtilis & $\begin{array}{l}\text { Co-crystallised maltopentaose and acarbose, } \\
\text { determined by multiple isomorphous } \\
\text { replacement. Restrained crystallographic } \\
\text { refinement has resulted in an } R \text {-factor of } \\
19.8 \% \text { in the } 7.0 \text { to } 2.5 \AA \text { resolution range }\end{array}$ & $2.5 \AA$ A resolution & {$[112]$} \\
\hline 3 & B. licheniformis & $\begin{array}{l}\text { Multiple isomorphous replacement in a } \\
\text { crystal of space group } P 4_{3} 2_{1} 2 \\
(a=b=119.6 \AA, c=85.4 \AA) \text {. }\end{array}$ & $2.2 \AA \AA$ resolution & [113] \\
\hline 4 & $\begin{array}{l}\text { B. licheniformis } 55,200 \mathrm{Da} \\
\text { (483 amino acid residues) }\end{array}$ & $\begin{array}{l}\text { Multiple isomorphous replacement method } \\
\text { of X-ray crystallography }\end{array}$ & $1.7 \AA ̊$ resolution & {$[69]$} \\
\hline 5 & B. stearothermophilus & & $2.0 \AA \AA$ resolution & {$[114]$} \\
\hline 6 & B. halmapalus & $\begin{array}{l}\text { Complex with the (pseudo) tetrasaccharide } \\
\text { inhibitor acarbose }\end{array}$ & $2.1 \AA ̊$ resolution & {$[115]$} \\
\hline
\end{tabular}




\section{APPLICATIONS OF $\alpha$-AMYLASE}

With the advent of new frontiers in biotechnology, the spectrum of the applications of amylase has been widened up to many other fields such as clinical, medicinal and analytical chemistries, as well as their widespread use in the industries such as textile, laundry, porcelain, detergents, paper, food, brewing, baking and distilling. If no suitable enzyme is available in nature, a suitable one will be designed to the choice of the industry as being done on $B$. licheniformis. The engineering works performed on $B$. licheniformis $\alpha$-amylase from over the last decade provide a good example of the extent to which an enzyme can be remodeled in order to improve its natural performance and thus to fulfill industrial requirements. Contrary to expectations, the thermal resistance of this highly thermostable $\alpha$-amylase is far from being maximised in the wild-type enzyme and there seems to exist many ways to increase the thermostability even further. A fair set of stabilising substitutions have already been found in B. licheniformis and many more may be identified in the future. Given the success achieved so far, it may even be possible to increase $B$. licheniformis thermostability beyond the most thermostable enzymes found in hyperthermophiles.

Table 5 shows that the bacillial $\alpha$-amylases are mainly employed in food, detergent, textiles, paper and pharmaceutical industries. Enzymes are commonly used in the baking industry, as they can improve dough quality and texture and lengthen the shelf life of the final product. There is a little published information is available which highlights exposure of enzymes (other than fungal $\alpha$ -amylase) to the baking industry [84]. $\alpha$-amylases have been used extensively in bread making to break down complex sugars such as starch (found in flour) into simple sugars [85]. Directed evolution coupled with a high-throughput robotic screen was employed to broaden the industrial use of the maltogenic $\alpha$-amylase, Novamyl obtained from Bacillus sp. TS-25 [86]. Wild-type No

Table 5. Major applications of $\alpha$-amylases obtained from Bacillus spp.

\begin{tabular}{|c|c|c|c|}
\hline SI. No. & Industry & Bacillus sp. & Reference \\
\hline \multirow{5}{*}{1} & \multirow{5}{*}{ Food industry } & Bacillus sp. TS-25 & {$[86]$} \\
\hline & & B. subtilis \& B. amyloliquefaciens & {$[84]$} \\
\hline & & B. subtilis & {$[100]$} \\
\hline & & B. megaterium & {$[12]$} \\
\hline & & B. licheniformis & [89] \\
\hline \multirow{7}{*}{2} & \multirow{7}{*}{ Detergent industry } & Bacillus. sp. A3-15 & {$[63]$} \\
\hline & & Bacillus. sp. strain SMIA-2 & {$[101]$} \\
\hline & & B. cohnii & {$[116]$} \\
\hline & & Bacillus strains & {$[87]$} \\
\hline & & B. licheniformis & {$[89]$} \\
\hline & & B. horikoshii & {$[91]$} \\
\hline & & Bacllus sp. $\mathrm{B}_{3}$ & {$[117]$} \\
\hline \multirow{3}{*}{3} & \multirow{3}{*}{ Textile industry } & Bacillus sp. A3-15 & {$[63]$} \\
\hline & & B. licheniformis & {$[89]$} \\
\hline & & Bacillus sp. $\mathrm{B}_{3}$ & {$[117]$} \\
\hline \multirow{2}{*}{4} & \multirow{2}{*}{ Paper industry } & Bacillus sp. NCIMB 40916 & {$[91]$} \\
\hline & & Bacillus sp. $\mathrm{B}_{3}$ & {$[117]$} \\
\hline \multirow{4}{*}{5} & \multirow{4}{*}{ Pharmaceutical industry } & B. licheniformis & {$[118]$} \\
\hline & & Bacillus sp. & [119] \\
\hline & & B. licheniformis & {$[7]$} \\
\hline & & Bacillus sp. & {$[85]$} \\
\hline
\end{tabular}


vamyl is currently used in the baking industry as an anti-staling agent in breads baked at neutral or near neutral $\mathrm{pH}$. However, the enzyme is rapidly inactivated during the baking process of bread made with low $\mathrm{pH}$ recipes and Novamyl thus has very limited beneficial effects for this particular application [86]. Alternatively, Rajagopalan and Krishnan [8] used glucose and maltose forming $\alpha$-amylases from $B$. subtilis in alcohol fermentation and sugar syrup formulation; and also for the food processing by malto-oligosaccharide forming $\alpha$-amylases.

The alkaline enzymes used in modern detergents are protease, cellulase, $\alpha$-amylase, lipase, and mannanase [87]. Like proteases, alkaline amylases play crucial role in detergents designed for washing machines $[62,88]$. Large quantities of alkaline enzymes are used in the detergent industry, and they have widely been incorporated into heavy-duty laundry and automatic dishwashing detergents. Though traditionally prepared from $B$. amyloliquefaciens, the amylase from $B$. licheniformis is getting growing market shares because of its greater thermostability [57].

The major uses of amylases extend to textile and paper industries also. For a number a of years, $\alpha$-amylases have been used for a variety of purposes; the most important of which are starch liquefaction, textile desizing, and starch modification in the paper and pulp industry [89]. One of its major uses is for the liquefaction of starch (reduction of high molecular mass to about 10 or 11 residues) in the starch processing and related industries and for the designing of textiles [90]. $\alpha$-amylase is used to produce modified starches for the paper industry to remove starch in the manufacturing of textiles (desising) [88]. In addition, amylases have potential industrial applications such as antisaling agent, production of cyclodextrins, sizing of textile fibres, and clarification of haziness in beer and fruit juices [4]. Variants of $B$. licheniformis $\alpha$-amylase exhibit applications in textile desizing [91], as the alkaline $\alpha$-amylase produed by $\mathrm{Ba}$ cillus sp. A3-15 [63].

With the advent of various novel strategies in the pharmaceutical and chemical industries, amylases have been emerged as a major player in the synthesis of optically pure drugs and agrochemicals [85]. A method of curing and preventing obesity comprises orally administrating $\alpha$-amylase inhibitor thereby inhibiting $\alpha$-amylase activity in saliva and pancreatic juice, and reducing digestion and absorption of starch (reduction of the calorie taken from meals). Obesity can be cured or prevented effectively while taking usual diet without giving any physical or mental pain by administering oral tablets containing amylase [92]. Owing to the starch degrading ability of bacterial $\alpha$-amylase - mostly from B. subtilis, it is widely used in pharmaceutical industry as an active ingredient in various digestive aid preparations. Due to the presence of $\alpha$-amylase, starch in the consumed food is better digested, this increases overall digestibility of food. Such digestive aid preparations are used for treatment of patients whose digesting power is reduced due to illness. These days, many such commercial formulations of digestive aids either as syrup or as tablet are seen in the shelves of many drug vebdors with very high demand.

\section{CONCLUSION}

Three amylases $(\alpha, \beta, \gamma)$ known to date in microbial world are much useful to the industry. Bifunctional industrially significant $\alpha$ and $\gamma$ amylase fusion proteins are already available to the industry. However, a trifunctional amylase embodying the catalytic activities of all known amylases is yet to be made available to the industry. Using available crystal structures and of other sequence informations on mammalian and microbial amylases, the structure of $\alpha$-amylase from novel strains of Bacillus can easily be predicted by homology modeling as long as we obtain apparently similar amino acid sequences. Moreover, occupational diseases associated with bacilliary amylase have to be addressed properly amidst the industrial values of microbial amylases. Occupational asthma is a major threat in workers engaged in industries, especially clothing and detergents sector. All these aspects highlight that though we use Bacillus with GRAS status (unlike B. anthracis and B. cereus) for amylase production, when they come to the industrial perspective, untoward risks have been sprouted up. These problems can be better solved by engineering such proteins with a view to improved enzymatic performance, including increased themostability and reduced calcium dependence. Industry demands an ideal $\alpha$-amylase with increased stability, durability, reusability - especially when used at immobilised state, or a trifunctional amylase embodying the functions of all amylases with maximum activity. Such a versatile fusion protein should be useful in starch processing, starch liquefaction, fermentation, starch saccharification, cleaning, laundrying, textile desizing, baking, and biofilm removal with least expense.

\section{ACKNOWLEDGEMENTS}

RBS and SS are grateful to the University of Calicut for research fellowships and VNJ is grateful to the Rajiv Gandhi Research Fellowship from University Grants Commission, Government of India.

\section{REFERENCES}

[1] Smitha, R.B. (2010) Dual production of endotoxin and amylase from Bacillus thuringiensis subsp. kurstaki by fermentation and efficacy studies of endotoxin against 
eriophyid mite, University of Calicut, Calicut.

[2] Benjamin, S. and Pandey, A. (1996) Lipase production by Candida rugosa on copra waste extract. Indian Journal of Microbiology, 36, 201-204.

[3] Pandey, A., Soccol, C.R. and Soccol, V.T. (2000) Biopotential of immobilized amylases. Indian Journal of Microbiology, 40, 1-14.

[4] Agrawal, M., Pradeep, S., Chandraraj, K. and Sathyanarayana, N.G. (2005) Hydrolysis of starch by amylase from Bacillus Sp. KCA102: A statistical approach. Process Biochemistry, 40, 2499-2507. doi:10.1016/i.procbio.2004.10.006

[5] Akkaya, B., Yenidünya, A.F. and Akkaya, R. (2012) Production and immobilization of a novel thermoalkalophilic extracellular amylase from bacilli isolate. International Journal of Biological Macromolecules, 50, 991-995. doi:10.1016/j.ijbiomac.2012.02.011

[6] Demirkan, E.S., Mikami, B., Adachi, M., Higasa, T., et al. (2005) Alpha amylase from B. amyloliquefaciens: Purification, characterization, raw starch degradation and expression in E. coli. Process Biochemistry, 40, 2629-2646. doi:10.1016/j.procbio.2004.08.015

[7] Kandra, L. (2003) $\alpha$-Amylases of medical and industrial importance. Journal of Molecular Structure, 666-667, 487498. doi:10.1016/j.theochem.2003.08.073

[8] Rajagopalan, G. and Krishnan, C. (2008) $\alpha$-amylase production from catabolite depressed Bacillus subtilis KCC103 utilizing sugarcane bagasse hydrolysate. Bioresource Technology, 99, 3044-3050.

doi:10.1016/j.biortech.2007.06.001

[9] Liu, Y., Lu, F., Chen, G., Snyder, C.L., et al. (2010) High-level expression, purification and characterization of a recombinant medium-temperature $\alpha$-amylase from Bacillus subtilis. Biotechnology Letters, 32, 119-124. doi:10.1007/s10529-009-0112-4

[10] Ye, Z., Miyake, H., Tatsumi, M., Nishimura, S., et al. (2004) Two additional carbohydrate-binding sites of $\alpha$ amylase from Bacillus cereus var. mycoides Are Involved in Hydrolysis and Raw Starch-Binding. Journal of Biochemistry, 135, 355-363. doi:10.1093/jb/mvh043

[11] Bijttebier, A., Goesaert, H. and Delcour, J.A. (2007) Temperature impacts the multiple attack action of amylases. Biomacromolecules, 8, 765-772. doi:10.1021/bm060784u

[12] Ray, R., Jana, S.C. and Nanda, G. (1994) $\beta$-Amylase from Bacillus megaterium. Folia Microbiologica, 39, 567-570. doi:10.1007/BF02814110

[13] Tateno, T., Fukuda, H. and Kondo, A. (2007) Production of L-Lysine from starch by Corynebacterium glutamicum displaying á-amylase on its cell surface. Applied Microbiology and Biotechnology, 74, 1213-1220. doi:10.1007/s00253-006-0766-y

[14] Kumar, P. and Satyanarayana, T. (2009) Microbial glucoamylases: Characteristics and applications. Critical Reviews in Biotechnology, 29, 225-255. doi:10.1080/07388550903136076

[15] Sivaramakrishnan, S., Gangadharan, D., Nampoothiri, K.M., Soccol, C.R., et al. (2006) $\alpha$-Amylases from microbial
sources-An overview on recent developments. Food Technology and Biotechnology, 44, 173-184.

[16] Tomazic, S.J. and Klibanov, A.M. (2003) Why is one Bacillus alpha-amylase more resistant against irreversible thermoinactivation than another. Journal of Biological Chemistry, 263, 3092-3096.

[17] Ajayi, A.E. and Fagade, O.E. (2006) Growth pattern and structural nature of amylases produced by some Bacillus species in starchy substrates. African Journal of Biotechnology, 5, 440-444.

[18] Narang, S. and Satyanarayana, T. (2001) Thermostable $\alpha$-amylase production by an extreme thermophile Bacillus thermooleovorans. Letters in Applied Microbiology, 32, 31-35. doi:10.1046/j.1472-765x.2001.00849.x

[19] Saui, Q., Bano, S., Iqbal, S., Syed, N., et al. (2006) Enhanced production and extracellular activity of commercially important amylolytic enzyme by a newly isolated strain of Bacillus. sp. AS-1. Turkish Journal of Biochemistry, 31, 135-140.

[20] Riaz, A., Qader, S., Anwar, A. and Iqbal, S. (2009) Immobilization of a thermostable alpha-amylase on calcium alginate beads from Bacillus Subtilis KIBGE-HAR. Australian Journal of Basic and Applied Sciences, 3, 28832887.

[21] Srivastava, R.A.K. and Baruah, J.N. (1986) Culture conditions for production of thermostable amylase by Bacillus stearothermophilus. Applied and Environmental Microbiology, 52, 179-184.

[22] Tsurikova, N.V., Nefedova, L.I., Kostyleva, E.V., Zvenigorodskii, V.I., et al. (2002) Selection of a potent Bacillus licheniformis strain producing thermostable amylase. Applied Biochemistry and Microbiology, 38, 427-432. doi:10.1023/A:1019960216770

[23] Ul-Haq, I., Ashraf, H., Ali, S. and Qadeer, M.A. (2005) Pearl millet, a source of alpha amylase production by $\mathrm{Ba}$ cillus lichenifirmis. Bioresource Technology, 96, 12011204. doi:10.1016/j.biortech.2004.09.012

[24] Rao, U.M. and Satyanarayana, T. (2007) Purification and characterization of a hyperthermostable and high maltogenic a-amylase of an extreme thermophile Geobacillus thermoleovorans. Applied Biochemistry and Biotechnology, 142, 179-193. doi:10.1007/s12010-007-0017-4

[25] Gargi, D., Singh, B. and Rintu, B. (2003) Immobilization of a-amylase produced by Bacillus circulans GRS 313. Brazilian Archives of Biology and Technology, 46, 167176.

[26] Tanyildizi, M.S., Ozer, D. and Elibol, M. (2004) Optimization of alpha amylase production by Bacillus sp. using response surface methedology. Process Biochemistry.

[27] Gangadharan, D., Sivaramakrishnan, S., Nampoothiri, K.M., Sukumaran, R.K., et al. (2008) Response surface methodology for the optimization of alpha amylase production by Bacillus amyloliquefaciens. Bioresource Technology, 99, 4597-4602. doi:10.1016/j.biortech.2007.07.028

[28] Rousset, S. and Schlich, P. (1989) Amylase production in submerged culture using principal component media. Journal of Fermentation and Bioengineering, 68, 339-343. 
doi:10.1016/0922-338X(89)90009-3

[29] Božić, N., Ruiz, J., López-Santín, J. and Vujčić, Z. (2011) Production and properties of the highly efficient raw starch digesting $\alpha$-amylase from a Bacillus licheniformis ATCC 9945a. Biochemical Engineering Journal, 53, 203209. doi:10.1016/j.bej.2010.10.014

[30] Benjamin, S. and Pandey, A. (1998) Candida rugosa lipases: Molecular biology and versatility in biotechnology. Yeast, 14, 1069-1087. doi:10.1002/(SICI)1097-0061(19980915)14:12<1069::AI D-YEA303>3.0.CO;2-K

[31] Pandey, A., Nigam, P., Soccol, C.R., Soccol, V.T., et al. (2000) Advances in microbial amylases. Biotechnology and Applied Biochemistry, 31, 135-152. doi:10.1042/BA19990073

[32] Ramesh, M.V. and Lonsane, B.K. (1987) Solid state fermentation for production of $\alpha$-amylase by Bacillus megaterium 16M. Biotechnology Letters, 9, 323-328. doi:10.1007/BF01025797

[33] Shukla, J. and Kar, R. (2006) Potato peel as a solid state substrate for thermostable $\alpha$-amylase production by thermophilic Bacillus isolates. World Journal of Microbiology \& Biotechnology, 22, 417-422. doi:10.1007/s11274-005-9049-5

[34] Vijayabaskar, P., Jayalakshmi, D. and Shankar, T. (2012) Amylase production by moderately halophilic Bacillus cereus in solid state fermentation. African Journal of Microbiology Research, 6, 4918-4926.

[35] Kokab, S., Asghar, M., Rehman, K., Asad, M.J., et al. (2003) Bio processing of banana peel for alpha amylase production by Bacillus subtilis. International Journal of Agriculture and Biology, 5, 36-39.

[36] Unakal, C., Kallur, R.I. and Kaliwal, B.B. (2012) Production of $\alpha$-amylase using banana waste by Bacillus subtilis under solid state fermentation. European Journal of Experimental Biology, 2, 1044-1052.

[37] Baysal, Z., Uyar, F. and Aytekin, C. (2003) Solid state fermentation for production of $\alpha$-amylase by a thermotolerant Bacillus subtilis from hot-spring water. Process Biochemistry, 38, 1665-1668. doi:10.1016/S0032-9592(02)00150-4

[38] Pandey, A., Benjamin, S., Soccol, C.R., Nigam, P., et al. (1999) The realm of microbial lipases in biotechnology. Biotechnology and Applied Biochemistry, 29, 119-131.

[39] Oguntoyinbo, F.A., Sanni, A.I., Franz, M.A.P. and Holzapfel, W.H. (2007) Phenotypic diversity and technological properties of Bacillus subtilis species isolated from okpehe, a traditional fermented condiment. World Journal of Microbiology \& Biotechnology, 23, 401-410. doi:10.1007/s11274-006-9238-X

[40] Benjamin, S. and Pandey, A. (1997) Coconut cake-A potent substrate for the production of lipase by Candida rugosa in solid state fermentation. Acta Biotechnologica, 17, 241-251. doi:10.1002/abio.370170308

[41] El-Tayeb, O., Mohammad, F., Hashem, A. and Aboulwafa, M. (2008) Optimization of the industrial production of bacterial alpha amylase in Egypt. IV. fermentor production and characterization of the enzyme of two strains of Bacillus subtilis and Bacillus amyloliquefaciens. African Journal of Biotechnology, 7, 4521-4536.

[42] Sodhi, H.K., Sharma, K., Gupta, J.K. and Soni, S.K. (2005) Production of a thermostable $\alpha$-amylase from Bacillus sp. PS-7 by solid state fermentation and its synergistic use in the hydrolysis of malt starch for alcohol production. Process Biochemistry, 40, 525-534. doi:10.1016/j.procbio.2003.10.008

[43] Yoon, M.Y., Yoo, Y.J. and Gadman, T.W. (1989) Phosphate effects in the fermentation of a-amylase by Bacillus amyloliquefaciens. Biotechnology Letters, 11, 57-60. doi:10.1007/BF01026787

[44] Enhasy, H.A.E. (2007) Bioprocess development for the production of alpha amylase by Bacillus amyloliquefaciens in Batch and Fed-Batch cultures. Research Journal of Microbiology, 2, 560-568. doi:10.3923/jm.2007.560.568

[45] Al-Qodah, Z., Daghstani, H., Geopal, P.H. and Lafi, W. (2007) Determination of kinetic parameters of alpha amylase producing thermophile Bacillus sphaericus. African Journal of Biotechnology, 6, 699-706.

[46] Khan, F.A.B.A. and Husaini, A.A.S.A. (2006) Enhancing a-amylase and cellulase in vivo enzyme expressions on sago pith residue using Bacilllus amyloliquefaciens UMAS 1002. Biotechnology, 5, 391-403. doi:10.3923/biotech.2006.391.403

[47] Mamo, G. and Gessesse, A. (1997) Thermostable amylase production by immobilized thermophilic Bacillus sp. Biotechnology Techniques, 11, 447-450. doi:10.1023/A:1018437310837

[48] Whitney, D.F., Toledo, R.T. and Hamdy, M.K. (2006) $\alpha$-Amylase synthesis by mutant of Bacillus subtilis immobilized onto channel alumina beads. Journal of Rapid Methods \& Automation in Microbiology, 14, 266-282. doi:10.1111/j.1745-4581.2006.00052.x

[49] Chevalier, P. and Nouee, J.D.I. (1987) Enhancement of $\alpha$-amylase production by immobilized Bacillus subtilis in an airlift fermenter. Enzyme and Microbial Technology, 9, 53-56. doi:10.1016/0141-0229(87)90049-4

[50] Konsoula, Z. and Liakopoulou-Kyriakides, M. (2006) Thermostable $\alpha$-amylase production by Bacillus subtilis entrapped in calcium alginate gel capsules. Enzyme and Microbial Technology, 39, 690-696.

doi:10.1016/j.enzmictec.2005.12.002

[51] Dobreva, E., Ivanova, V., Tonkova, A. and Radulova, A. (1996) Influence of the immobilization conditions on the efficiency of $\alpha$-amylase production by Bacillus licheniformis. Process Biochemistry, 31, 229-234. doi:10.1016/0032-9592(95)00052-6

[52] Groom, C.A., Daugulis, A.J. and White, B.N. (1988) Continuous alpha-amylase production using Bacillus amyloliquefaciens adsorbed on an ion exchange resin. Applied Microbiology and Biotechnology, 28, 8-13. doi:10.1007/BF00250489

[53] Nilesh, A., Kamat, M. and Lali, A. (2004) Expanded bed affinity purification of bacterial-amylase and cellulase on composite substrate analogue-cellulose matrices. Process Biochemistry, 39, 565-570. doi:10.1016/S0032-9592(03)00123-7 
[54] Shewale, S.D. and Pandit, A.B. (2007) Hydrolysis of soluble starch using Bacillus licheniformis $\alpha$-amylase immobilized on superporous CELBEADS. Carbohydrate Research, 342, 997-1008. doi:10.1016/j.carres.2007.02.027

[55] Borgio, J.F. (2011) Immobilization of microbial (wild and mutant strains) amylase on coconut fiber and alginate matrix for enhanced activity. American Journal of Biochemistry and Molecular Biology, 1, 255-264. doi:10.3923/ajbmb.2011.255.264

[56] Tarek, E., El-Banna, Ahmed, A., Abd-Aziz., et al. (2008) Optimization and immobilization of $\alpha$-amylase from $B a$ cillus licheniformis. The Egyptian Society for Environmental Science, 3, 14-25.

[57] Hmidet, N., Bayoudh, A., Berrin, J.G., Kanoun, S., et al. (2008) Purification and biochemical characterization of a novel $\alpha$-amylase from Bacillus licheniformis NH1: Cloning, nucleotide sequence and expression of amyn gene in Escherichia coli. Process Biochemistry, 43, 499-510. doi:10.1016/i.procbio.2008.01.017

[58] Sanoja, R.R., Guyot, J.M., Jore, J., Pintado, J., et al. (2000) Comparative characterization of complete and truncated forms of Lactobacillus amylovorus alpha amylase and role of the $\mathrm{C}$-terminal direct repeats in raw starch binding. Applied and Environmental Microbiology, 66, 3350-3356. doi:10.1128/AEM.66.8.3350-3356.2000

[59] Rao, M.D., Ratnam, B., Dasari, V.D. and Ayyanna, C. (2005) Rapid method for the affinity purification of thermostable $a$-amylase from Bacillus licheniformis. World Journal of Microbiology \& Biotechnology, 21, 371-375. doi:10.1007/s11274-004-3908-3

[60] Krishnan, T. and Chandra, A.K. (1983) Purification and characterization of $\alpha$-amylase from Bacillus licheniformis CUMC305. Applied and Environmental Microbiology, 46, 430-437.

[61] Vengadaramana, A., Balakumar, S. and Arasaratnam, V. (2012) Stimulation of thermal stability of $\alpha$-amylase from Bacillus icheniformis ATCC 6346 by treating with cations. Ceylon Journal of Science (Biological Sciences), 41, 35-44.

[62] Bernhardsdotter, E.C., Ng, J.D., Garriott, O.K. and Pusey, M.L. (2005) Enzymic properties of an alkaline chelatorresistant $\alpha$-amylase from an alkaliphilic Bacillus sp. isolate L1711. Process Biochemistry, 40, 2401-2408. doi:10.1016/j.procbio.2004.09.016

[63] Arikan, B. (2008) Highly thermostable, thermophilic, alkaline, SDS and chelator resistant amylase from a thermophilic Bacillus sp. isolate A3-15. Bioresource Technology, 99, 3071-3076. doi:10.1016/j.biortech.2007.06.019

[64] Liu, Y., Lu, F., Li, Y., Yin, X., et al. (2008) alpha-amylase expressed in Bacillus subtilis WB600. Applied Microbiology and Biotechnology, 78, 85-94. doi:10.1007/s00253-007-1287-Z

[65] Nagarajan, D.R., Rajagopalan, G. and Krishnan, C. (2006) Purification and characterization of a maltooligosaccharide-forming $\alpha$-amylase from a new Bacillus subtilis KCC103. Applied Microbiology and Biotechnology, 73, 591-597. doi:10.1007/s00253-006-0513-4

[66] Ezeji, T. and Bahl, H. (2006) Purification, characteriza- tion and synergistic action of phytate resistant alpha amylase and alpha glucosidase from Geobacillus thermodenitrificans HRO10. Journal of Biotechnology, 125, 27-38. doi:10.1016/j.jbiotec.2006.02.006

[67] Natalia, D., Yuliani, Y., Ermayadhie, Y., Putra, R., et al. (2006) Thermostable glucoamylase-type enzyme from Bacillus acidocaldarius RP1. Biochemistry and Molecular Biology Education, 30, 398-400. doi:10.1002/bmb.2002.494030060137

[68] Konsula, Z. and Liakopoulou-Kyriakides, M. (2004) Hydrolysis of starches by the action of an $\alpha$-amylase from Bacillus subtilis. Process Biochemistry, 39, 1745-1749. doi:10.1016/j.procbio.2003.07.003

[69] Hwang, K.Y., Song, H.K., Chang, C., Lee, J., et al. (1997) Crystal structure of thermostable alpha-amylase from $\mathrm{Ba}$ cillus licheniformis refined at 1.7 A resolution. Molecules and Cells, 7, 251-258.

[70] Liu, Y.H., Lu, F.P., Wang, J.L. and Gao, C. (2008) Acid stabilization of Bacillus licheniformis alpha amylase through introduction of mutations. Applied Microbiology and Biotechnology, 80, 795-803. doi:10.1007/s00253-008-1580-5

[71] Ivanova, V.N., Dobreva, E.P. and Emanuilova, E.I. (1993) Purification and characterization of a thermostable alphaamylase from Bacillus licheniformis. Journal of Biotechnology, 28, 277-289. doi:10.1016/0168-1656(93)90176-N

[72] Femi-Ola, T.O. and Olowe, B.M. (2011) Characterization of alpha amylase from Bacillus subtilis BS5 Isolated from amitermes evuncifer silvestri. Research Journal of Microbiology, 6, 140-146. doi:10.3923/jm.2011.140.146

[73] Ozcan, B.D., Baylan, M., Ozcan, N. and Tekdal, D. (2010) Characterization of thermostable $\alpha$-amylase from thermophilic and alkaliphilic Bacillus sp. Isolate DM-15. Research Journal of Biological Sciences, 5, 118-124. doi:10.3923/rjbsci.2010.118.124

[74] Nakajima, R., Imanaka, T. and Aiba, S. (1985) Nucleotide sequence of the Bacillus stearothermophilus alphaamylase gene. Journal of Bacteriology, 163, 401-406.

[75] Igarashi, K., Hatada, Y., Hagihara, H., Saeki, K., et al. (1998) Enzymatic properties of a novel liquefying-amylase from an alkaliphilic Bacillus Isolate and entire nucleotide and amino acid sequences. Applied and Environmental Microbiology, 64, 3282-3289.

[76] Marco, J.L., Bataus, L.A., Valência, F.F., Ulhoa, C.J., et al. (1996) Purification and characterization of a truncated Bacillus subtilis alpha-amylase produced by Escherichia coli. Applied Microbiology and Biotechnology, 44, 746752.

[77] Ohdan, K., Kuriki, T., Kaneko, H., Shimada, J., et al. (1999) Characteristics of two forms of alpha amylases and structural implication. Applied and Environmental Microbiology, 65, 4562-4568.

[78] Suzuki, Y., Ito, N., Yuuki, T., Yamagata, H., et al. (2006) Amino acid residues stabilizing a Bacillus alpha-amylase against irreversible thermoinactivation. Biochemistry, 139, 997-1005.

[79] Stam, M.R., Danchin, E.G.J., Rancurel, C., Coutinho, P.M., et al. (2006) Dividing the large glycoside hydrolase family 13 into subfamilies: towards improved functional 
annotations of $\alpha$-amylase-related proteins. Protein Engineering Design \& Selection, 19, 555-562.

doi:10.1093/protein/gzl044

[80] Machius, M., Declerck, N., Huber, R. and Wiegand, G. (1998) Activation of Bacillus licheniformis $\alpha$-amylase through a disorder $\rightarrow$ order transition of the substratebinding site mediated by a calcium-sodium-calcium metal triad. Structure, 6, 281-292. doi:10.1016/S0969-2126(98)00032-X

[81] Watanabe, T., Yamamoto, A., Nagai, S. and Terabe, S. (1998) Simultaneous measurement of -amylase and glucoamylase activities in sake rice koji by capillary electrophoresis of sodium dodecyl sulfate-protein complexes and activity measurement of glucoamylase by in-capillary enzyme reaction method. Electrophoresis, 19, 2331-2337.

[82] Vega, M.C., Lorentzen, E., Linden, A. and Wilmanns, M. (2003) Evolutionary markers in the $(\beta / \alpha)_{8}$-barrel fold. Current Opinion in Chemical Biology, 7, 674-701. doi:10.1016/j.cbpa.2003.10.004

[83] Declerck, N., Machius, M., Joyet, P., Wiegand, G., et al. (2003) Hyperthermostabilization of Bacillus licheniformis-amylase and modulation of its stability over a $50^{\circ} \mathrm{C}$ temperature range. Protein Engineering, 16, 287-293. doi:10.1093/proeng/gzg032

[84] Elms, J., Robinson, E., Mason, H., Iqbal, S., et al. (2006) Enzyme exposure in the British baking industry. Annals of Occupational Hygiene, 50, 379-384. doi:10.1093/annhyg/mei080

[85] Samrot, A.V. and Vijay, A. (2009) $\alpha$-Amylase activity of wild and mutant strains of Bacillus sp. The Internet Journal of Microbiology, 6, 2.

[86] Jones, A., Lamsa, M., Frandsen, T., Spendler, T., et al. (2008) Directed evolution of a maltogenic $\alpha$-amylase from Bacillus sp. TS-25. Journal of Biotechnology, 134, 325333. doi:10.1016/i.jbiotec.2008.01.016

[87] Ito, S., Kobayashi, T., Hatada, Y. and Horikoshi, K. (2005) Enzymes in modern detergents. Methods in Biotechnology, 17, 151-161.

[88] Lee, S., Oneda, H., Minoda, M., Tanaka, A., et al. (2006) Comparison of starch hydrolysis activity and thermal stability of two Bacillus licheniformis $\alpha$-amylases and insights into engineering a-amylase variants active under acidic conditions. Journal of Biochemistry, 139, 997-1005. doi:10.1093/jb/mvi113

[89] Shaw, A., Ramer, S.W., Power, S.D., Shetty, J.K., et al. (2009) Variants of Bacillus licheniformis alpha-amylase with increased thermostability and/or decreased calcium dependence. US Patent No. 20090238923.

[90] Liu, X.D. and Xu, Y. (2008) A novel raw starch digesting alpha amylase from a newly isolated bacillus $s p$. YX-1: Purification and characterization. Bioresource Technol$o g y$, 99, 4315-4320. doi:10.1016/j.biortech.2007.08.040

[91] Hoff, T., Patkar, S.A. and Tams, J.W. (2010) Alkaline bacillus amylase. US Patent No. 7659101B2.

[92] Oishi, H.J., Hattori, T.J., Watanabe, M.J. and Kato, A.J. Method of curing and preventing obesity by alpha-amylase inhibitor. European Patent Application EP0451436 E.P.
[93] Mishra, S. and Behera, N. (2008) Amylase activity of a starch degrading bacteria isolated from soil receiving kitchen wastes. African Journal of Biotechnology, 7, 3326-3331.

[94] Huang, H., Ridgway, D., Gu, T. and Moo-Young, M. (2004) Enhanced amylase production by Bacillus subtilis using a dual exponential feeding strategy. Bioprocess and Biosystems Engineering, 27, 63-69. doi:10.1007/s00449-004-0391-z

[95] Hashim, S.O., Delgado, O., Hatt-Kaul, R., Mulaa, F.J., et al. (2004) Starch hydrolysing Bacillus halodurans isolates from a Kenyan soda lake. Biotechnology Letters, 26, 823-828. doi:10.1023/B:BILE.0000025885.19910.d7

[96] Heng, C., Chen, Z., Du, L. and Lu, F. (2005) Expression and secretion of an acid-stable $a$-amylase gene in Bacillus subtilis by SacB promoter and signal peptide. Biotechnology Letters, 27, 1731-1736. doi:10.1007/s10529-005-2743-4

[97] Kiran, K.K. and Chandra, T.S. (2008) Production of surfactant and detergent-stable, halophilic, and alkalitolerant alpha-amylase by a moderately halophilic Bacillus sp. Strain TSCVKK. Applied Microbiology and Biotechnology, 77, 1023-1031. doi:10.1007/s00253-007-1250-z

[98] Ramesh, M.V. and Lonsane, B.K. (1991) Regulation of alpha-amylase Production in Bacillus licheniformis M27 by enzyme end-products in submerged fermentation and its overcoming in solid state fermentation system. Biotechnology Letters, 13, 335-360. doi:10.1007/BF01027682

[99] Kelly, C.T., Bolton, D.J. and Fogarty, W. (1997) Bi-phasic production of a-amylase of Bacillus flavothermusin batch fermentation. Biotechnology Letters, 19, 675-677. doi:10.1023/A:1018347017004

[100] Asgher, M., Asad, M.J., Rahman, S.U. and Legge, R.L. (2007) A thermostable $\alpha$-amylase from a moderately thermophilic Bacillus subtilis strain for starch processing. Journal of Food Engineering, 79, 950-955. doi:10.1016/i.jfoodeng.2005.12.053

[101] Carvalho, R.V., Côrrea, T.L.R., da Silva, J.C.M., de Oliveira Mansur, L.R.C., et al. (2008) Properties of an amylase from thermophilic Bacillus SP. Brazilian Journal of Microbiology, 39.

[102] Ramesh, M.V. and Lonsane, B.K. (1989) Solid state fermentation for production of higher titres of thermostable alpha-amylase with two peaks for $\mathrm{pH}$ optima by Bacillus licheniformis M27. Biotechnology Letters, 11, 49-52. doi:10.1007/BF01026785

[103] Baysal, Z., Uyar, F., Aytekin, C., Doru, M., et al. (2008) Production of extracellular alkaline-amylase by solid state fermentation with a newly isolated Bacillus sp. Preparative Biochemistry and Biotechnology, 38, 184-190. doi:10.1080/10826060701885167

[104] Anto, H., Trivedi, U. and Patel, K. (2006) Alpha amylase production by Bacillus cereus MTCC 1305 using solidstate fermentation. Food Technology and Biotechnology, 44, 241-245.

[105] Gangadharan, D., Sivaramakrishnan, S., Nampoothiri, K.M., Sukumaran, R.K., et al. (2006) Solid culturing of Bacillus amyloliquefaciens for alpha amylase production. Food Technology and Biotechnology, 44, 296-274. 
[106] Omafuvbe, B. (2008) Effect of temperature on biochemical changes induced by Bacillus Subtilis (SDA3) during starter culture fermentation of soybean into condiment (soy-daddawa). American Journal of Food Technology, 3, 33-41. doi:10.3923/ajft.2008.33.41

[107] Soumen, P. and Rintu, B. (2001) Optimization of extraction parameters for recovery of A-amylase from the fermented bran of Bacillus circulans GRS313. Brazilian Archives of Biology and Technology, 44, 107-111.

[108] Liu, Y.H., Lu, F.P., Li, Y., Yin, X.B., et al. (2008) Characterisation of mutagenised acid resistant alpha-amylase expressed in Bacillus subtilis WB600. Applied Microbiology and Biotechnology, 78, 85-94. doi: $10.1007 / \mathrm{s} 00253-007-1287-\mathrm{z}$

[109] Das, K., Doley, R. and Mukherjee, A.K. (2004) Purification and biochemical characterization of a thermostable, alkaliphilic, extracellular á-amylase from Bacillus subtilis DM-03, a strain isolated from the traditional fermented food of India. Biotechnology and Applied Biochemistry, 40, 291-298. doi:10.1042/BA20040034

[110] Huang, H.B., Chi, M.C., Hsu, W.H., Liang, W.C., et al. (2005) Construction and one-step purification of Bacillus kaustophilusleucine aminopeptidase fused to the starchbinding domain of Bacillus sp. strain TS-23 a-amylase. Bioprocess and Biosystems Engineering, 27, 389-398. doi:10.1007/s00449-005-0001-8

[111] Nonaka, T., Fujihashi, M., Kita, A., Hagiharas, H., et al. (2003) Crystal structure of calcium-free alpha amylase from Bacillus sp. Strain KSM-K 38 (Amy K38) and its sodium binding sites. The Journal of Biological Chemistry, 278, 24818-24824. doi:10.1074/jbc.M212763200

[112] Fujimoto, Z., Takase, K., Doui, N., Momma, M., et al. (1998) Crystal structure of a catalytic-site mutant $\alpha$-amylase from Bacillus subtilis complexed with maltopentaose. Journal of Molecular Biology, 277, 393-407. doi:10.1006/jmbi.1997.1599

[113] Machius, M., Wiegand, G. and Huber, R. (1995) Crystal structure of calcium-depleted Bacillus licheniformis $\alpha$ amylase at $2.2 \AA$ Resolution. Journal of Molecular Biology, 246, 545-559. doi:10.1006/jmbi.1994.0106

[114] Suvd, D., Fujimoto, Z., Takase, K., Matsumura, M., et al. (2001) Crystal structure of Bacillus stearothermophilus a-Amylase: Possible factors determining the thermostability. Journal of Biochemistry, 129, 461-468. doi:10.1093/oxfordjournals.jbchem.a002878

[115] Davies, G.J., Brzozowski, A.M., Dauter, Z., Rasmussen, M.D., et al. (2005) Structure of a Bacillus halmapalus family 13-amylase, BHA, in complex with an acarbosederived nonasaccharide at $2.1 \AA$ resolution. Acta Crystallographica, 61, 190-193

[116] Ghorbel, R.E., Maktouf, S., Massoud, E.B., Bejar, S., et al. (2009) New thermostable amylase from Bacillus cohnii US147 with a broad pH applicability. Applied Biochemistry and Biotechnology, 157, 50-60. doi:10.1007/s12010-008-8278-0

[117] Thippeswamy, S., Girigowda, K. and Mulimani, V.H. (2006) Isolation and identification of alpha amylase producing Bacillus sp. from dhal industry waste. Indian Journal of Biochemistry and Biophysics, 43, 295-298.

[118] Ul-Haq, I., Ashraf, I.I., Iqbal, J. and Qadeer M.A. (2003) Production of alpha amylase by Bacillus licheniformis using an economical medium. Bioresource Technology, 87, 57-61. doi:10.1016/S0960-8524(02)00198-0

[119] Reilly, P. (2007) Amylase and Cellulase Structure and function. In: Yang, S.T., Ed., Bioprocessing for ValueAdded Products from Renewable Resources. New Technologies and Applications, Elsevier Press, Amsterdam, 119130. doi:10.1016/B978-044452114-9/50006-2 